William F. Casey MB FFarCs1, Charles E. Smith MD FRCP, Joel M. Katz MD FRCP, Kathleen O'Loughlin MB FFARCS], Sally K. Weeks MB FFARCs

\section{Intravenous meperidine for control of shivering during Caesarean section under epidural anaesthesia}

Shivering is a well recognized side effect of epidural anaesthesia. ${ }^{1-3}$ It is distressing to the patient, interferes with monitoring dcvices and increases oxygen consumption and cardiac output. ${ }^{4.5}$ Intravenous meperidine has been employed successfully to treat shivering following general anaesthesia, ${ }^{7}$ amphotericin chemotherapy, ${ }^{8}$ and cardiac surgery. ${ }^{9}$ The study was designed to evaluate the efficacy and safety of intravenous meperidine in controlling shivering during epidural anaesthesia for Caesarean section. epidural placement, skin incision, deliv tion of meperidine resulted in a significan decrease in both the overall incidence of shivering $(87$ to 35 per cent, $p<0.01$ ) and severity of shivering (grade 3: 57 to 0 per cent, $p<0.01$ ), compared with saline (incidence: 87 to 83 per cent, grade 3:57 per cent. no change). This effect was apparent within two minutes of drug injection and persisted throughout the study period. There were no differences in vital signs, oxygen saturation or temperature between groups. The incidence of nausea was similar, although patients receiving meperidine were more drowsy at two and five minutes following injection $(p<0.01)$ compared with patients in the saline group. There were no differences in level of consciousness at the later intervals. The mechanism of action of meperidine on shivering remains to be elucidated.

Key words

ANAESTHESIA: ObStetriCS; ANAESTHESIA TECHNIQUES: epidural; COMPLICATIONS: shivering; ANALGESICS, NaRCoric: intravenous meperidine.

From the Department of Anaesthesia, Royal Victoria Hospital and McGil! University, Montreal, Quebec.

Address correspondence to: Dr. Charles E. Smith, Department of Cardiothoracic Anesthesia, Cleveland Clinic, 9500

Euclid Avenue, Cleveland, Ohio, 44106 .

\section{Methods}

The protocol was approved by the Hospital Ethics Committee. Informed consent was obtained from each patient. Forty-six patients (ASA physical status I) undergoing Caesarean section with epidural anaesthesia were studied. Patients with known sensitivity to meperidine, or with any obstetrical or anaesthetic condition that might dictate against the use of regional anaesthesia, were excluded.

The epidural catheter was inserted at the $\mathrm{L}_{2-3}$ or $\mathrm{L}_{3-4}$ interspace at the time of Caesarean section (12 patients), unless previously placed for analgesia during labor (34 patients). After fluid loading with $1-2 \mathrm{~L}$ of 0.9 per cent saline, carbonated two per eent lidocaine with $1: 200,000$ epinephrine was given in $4 \mathrm{ml}$ increments via the epidural catheter to achieve an adequate block. Arterial pressure, electrocardiograph, oxygen saturation, respiratory rate and tympanic membrane temperature were monitored continuously. Oxygen, $6 \mathrm{~L} \cdot \mathrm{min}^{-1}$, was administered via a plastic face mask.

After delivery of the infant, patients received a single dose of intravenous meperidine $50 \mathrm{mg}$ or 0.9 per cent saline in a randomized double-blind fashion. If not shivering at the time of delivery, the patient did not receive intravenous treatment, and no further measuremonts were recorded. Shivering was classified as $0=$ none, $\mathbf{I}=$ mild, but not distressing to the patient, 2 = moderate and distressing, $3=$ severe, distressing, and interfering with monitoring. Potential side effects of meperidine such 
as nausea, vomiting or diminished respirations were carefully noted. Level of consciousness was classified as $0=$ asleep, $0.5=$ drowsy but arousable, and $1=$ awake. Shivering and other variables were recorded at epidural placement, skin incision, delivery, and $2,5,15,30$ and 60 minutes following injection of meperidine or saline. All patients received an infusion of syntocinon $\left(20\right.$ units $\mathrm{L}^{-l}$ ) following clamping of the umbilical cord, and a single dose of epidural fentanyl $(50 \mu \mathrm{g}$ diluted in $10 \mathrm{ml} 0.9 \mathrm{per}$ cent saline) 30 minutes after delivery.

Data were analyzed by Chi Square with Yates' correction for continuity, Wilcoxon's rank sum test, analysis of variance, and Student's t test where applicable. ${ }^{10-12}$ The results are expressed as mean values ( \pm SEM). A p value $<0.05$ was considered significant.

\section{Results}

Forty patients received meperidine or saline for shivering $(n=20$ in each group). The remaining six patients did not receive intravenous treatment as they were not shivering at the time of delivery. The groups were similar with respect to age (meperidine: $29.2 \pm 1.1$ years, vs saline: $27.9 \pm 1.4$ years) and height (meperidine: $158.7 \pm 1.3$ $\mathrm{cm}$, vs saline: $157.7 \pm 1.0 \mathrm{~cm}$ ), although the mean weight of the saline group was less than that of the meperidine group ( $69.2 \pm 2.3 \mathrm{vs} 78.6 \pm 2.6 \mathrm{~kg}, \mathrm{p}<0.05)$. The majority of patients in both groups were primigravidas (16 meperidine, 12 saline) undergoing emergency Caesarean section. The indication for Caesarean section was usually cephalopelvic disproportion and failure to progress (28 patients) or malpresentation (seven patients). The dura-

TABLE 1 Number of patients experiencing varying degrees of shivering prior to epidural lidocaine (Epid), at skin incision (Inc), delivery (Del), and following administration of intravenous meperidine or saline, $\dagger$ (Scc text for classification of shivering).

\begin{tabular}{|c|c|c|c|c|c|c|c|c|}
\hline & \multirow[b]{2}{*}{ Epid } & \multirow[b]{2}{*}{ Inc } & \multirow[b]{2}{*}{ Del } & \multicolumn{5}{|c|}{ Minutes post delivery } \\
\hline & & & & 2 & 5 & 15 & 30 & 60 \\
\hline \multicolumn{9}{|l|}{ Meperidine } \\
\hline None & 13 & 4 & 3 & 15 & 18 & 20 & 17 & 18 \\
\hline Mild & 4 & 1 & 0 & 4 & 1 & 2 & 5 & 4 \\
\hline Moderate & 2 & 5 & 7 & 4 & 4 & 1 & $\mathbf{I}$ & I \\
\hline Severe & 4 & 13 & 13 & 0 & 0 & 0 & 0 & 0 \\
\hline \multicolumn{9}{|l|}{ Saline } \\
\hline None & 8 & 3 & 3 & 4 & 6 & 6 & 5 & 9 \\
\hline Mild & 1 & 2 & 1 & 1 & 1 & 4 & 3 & 5 \\
\hline Moderalte & 6 & 5 & 6 & 7 & 5 & 6 & 6 & 6 \\
\hline Severe & 8 & 13 & 13 & 11 & 11 & 7 & 9 & 3 \\
\hline
\end{tabular}

$p<0.01$ between groups for all abservation periods following deliwery (Wilcoxon's rank sum).

t3 patients in each group did not receive intravenous treatment as they were not shivering at the time of delivery.

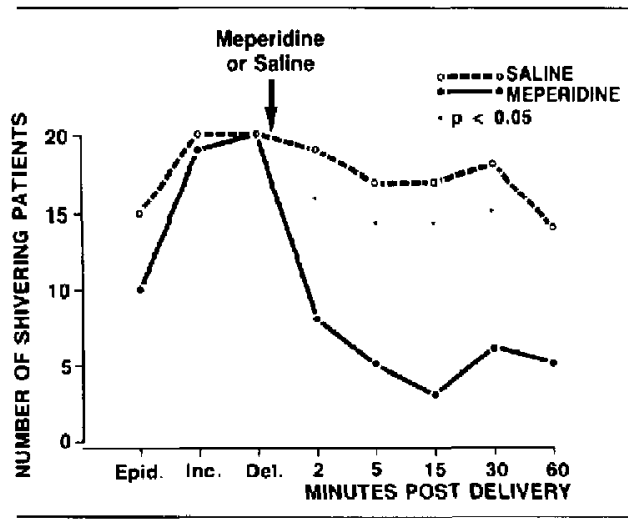

FIGURE I Number of patients shivering during Caesarean section prior to epidural lidocaine (Epid), at skin incision (Enc). delivery (Del), and fallowing intravenous administration of meperidine or salinc.

tion of labour prior to Caesarean section was similar between groups, being $12.3 \pm 2.2$ hours for meperidine and $8.4 \pm 2.2$ hours for the saline group $(p>0.1)$. The dosc of epidural lidocaine $(17.4 \pm 1.6 \mathrm{ml}$ meperidine group vs $19.3 \pm 0.7 \mathrm{ml}$ saline) and level of block achieved were similar between groups. There were no differences in time of skin or uterine incision to time of delivery, or total duration of surgery between the meperidine and saline groups $(7.3 \pm 0.9 \mathrm{vs} 6.4 \pm 0.6 \mathrm{~min}, 1.6 \pm 0.2 \mathrm{vs}$ $1.7 \pm 0.1 \mathrm{~min}$, and $46.3 \pm 5.3$ vs $48.2 \pm 2.7 \mathrm{~min}$, respectively).

The incidence of shivering before administration of epidural lidocaine was 43 per cent in the meperidine group and 65 per cent in the saline group (Table 1). By delivery, nearly all patients in both groups were shivering (40 of 46 parturients\%, the majority experiencing severe grade 3 shivering ( 57 per cent). Administration of intravenous meperidine resulted in a significant decrease in the incidence ( $p<0.01$, Chi Square) and severity ( $p<0.01$, Wilcoxon's rank sum) of shivering compared with saline (Figures I and 2, Table I). This effect was apparent within 2 min, and persisted throughout the study period.

There were no significant differences in blood pressure, heart rate, oxygen saturation, respiratory rate or temperature between the two groups before or after administration of meperidine or saline (Table Il). The incidence of nausea was similar between groups (meperidine nine patients, salinc cight patients). Supplemental drug requirements (diazepam and droperidol) were simllar between the meperidine (four and nine patients) and saline groups (seven and eight patients), respectively. Patients receiving meperidine were significantly more drowsy at 2 and 5 min following injection $(p<0.01$, 


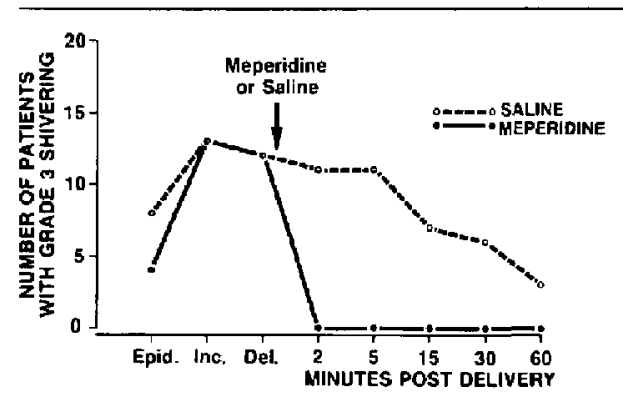

FIGURE 2 Number of patients experiencing grade 3 shivering (severe, distressing shivering that interfered with monitoring). Time intervals as in Figure $1 . P<0.01$ between groups at all time intervals following the administration of the study drug (Wilcoxon's rank sum (est).

Wilcoxon's rank sum) although there were no differences in levels of consciousness between groups at the later intervals (Tablc III).

\section{Discussion}

The incidence of shivering in parturients receiving epidural analgcsia varies between 20 and 50 per cent..$^{3,13,14}$ It is also recognized that shivering may occur during labour and delivery in the absence of epidural anaesthesia. ${ }^{1,2}$
TABLE III Level of consciousness following injection of meperidine or saline (number of patients per group).* All patients were awake prior to the sludy drug

\begin{tabular}{|c|c|c|c|c|c|}
\hline & \multicolumn{5}{|c|}{ Minutes } \\
\hline & 2 & 5 & 15 & 30 & 60 \\
\hline \multicolumn{6}{|c|}{ Meperidine } \\
\hline Awake & II & 7 & 10 & 9 & 10 \\
\hline Drowsy & 6 & 9 & 4 & 5 & 4 \\
\hline Asleep & 3 & 4 & 6 & 6 & 6 \\
\hline \multicolumn{6}{|l|}{ Saline } \\
\hline Awake & 19 & 17 & 15 & 12 & 10 \\
\hline Drowsy & 1 & 3 & 2 & 3 & 6 \\
\hline Asleep & 0 & 0 & 3 & 5 & 4 \\
\hline
\end{tabular}

$p<0.01$ between groups at 2 - and 5 -minute observation periods (Wilcokon's rank sum).

Min refers to minutes after treatment drug.

*Data are only for patients receiving intravenous treatment for shivering ( $\mathbf{n}=20$ in each group).

Intense and uncontrollable shivering in the obstetrical setting interferes with monitoring of the arterial pressure, electrocardiograph and oxygen saturation. In addition, studies of non-abstetrical shivering have documented the potential deleterious effect of this complication. Postanaesthetic shivering may increase oxygen consumption up to 500 per cent, increase cardiac work, decrease mixed

TABLE II Systolic arterial pressure in mmHg (SAP), heart rate (HR) beats per min, temperature (T) ${ }^{\circ} \mathrm{C}$, respiratory rate (RR) breaths per min, and oxygen saturation $\left(\mathrm{SaO}_{2}\right)$ per cent during the study period, $\mathrm{M}=$ Meperidine grcup, $\mathrm{S}=\mathrm{Saline}$. Mean $\pm \mathrm{SEM}$

\begin{tabular}{|c|c|c|c|c|c|c|c|c|}
\hline & \multirow[b]{2}{*}{ Epid } & \multirow[b]{2}{*}{ inc } & \multirow[b]{2}{*}{ Del } & \multicolumn{5}{|l|}{ Minutes } \\
\hline & & & & 2 & 5 & 1.5 & 30 & 60 \\
\hline \multicolumn{9}{|c|}{ SAP } \\
\hline $\mathbf{M}$ & $126 \pm 3$ & $120 \div 4$ & $117 \pm 3$ & $117=4$ & $118 \pm 3$ & $113 \pm 3$ & $113 \pm 3$ & $115 \pm 4$ \\
\hline$s$ & $121 \pm 3$ & $1] 7 \pm 2$ & $116 \pm 2$ & $115 \pm 3$ & $116 \pm 3$ & $112 \pm 3$ & $113 \pm 3$ & $110 \pm 4$ \\
\hline \multicolumn{9}{|c|}{$H R$} \\
\hline $\mathbf{M}$ & $101 \pm 4$ & $106=3$ & $114 \pm 3$ & $113 \pm 3$ & $109 \pm 3$ & $105 \pm 3$ & $104 \pm 4$ & $97 \pm 3$ \\
\hline $\mathbf{s}$ & $102 \pm 3$ & $113 \pm 4$ & $117 \pm 5$ & $118 \pm 5$ & $116 \pm 5$ & $114 \pm 5$ & $116 \pm 5$ & $109 \pm 5$ \\
\hline \multicolumn{9}{|l|}{$T$} \\
\hline $\mathrm{M}$ & $36.1 \pm 0.2$ & $36.0 \pm 0.2$ & $36.0 \pm 0.2$ & $36.0 \pm 0.2$ & $36.0 \pm 0.2$ & $35.9 \pm 0.2$ & $35.7 \pm 0.2$ & $35.8 \pm 0.2$ \\
\hline$s$ & $36.3 \pm 0.2$ & $36.3 \pm 0.3$ & $36.2 \pm 0.3$ & $36.2 \pm 0.2$ & $36.1 \pm 0.3$ & $36.2 \pm 0.2$ & $36.2 \pm 0.2$ & $36.2 \pm 0.3$ \\
\hline \multicolumn{9}{|c|}{$R \boldsymbol{R}$} \\
\hline M & $18 \pm 1$ & $18=1$ & $18 \pm 1$ & $17 \pm 1$ & $17=1$ & $16 \pm 1$ & $16 \pm 1$ & $16 \pm 1$ \\
\hline $\mathbf{S}$ & $17 \pm 1$ & $19 \pm 1$ & $19 \pm 1$ & $19 \pm 1$ & $19 \pm 1$ & $17 \pm 1$ & $17 \pm 1$ & $16 \pm 1$ \\
\hline \multicolumn{9}{|c|}{$\mathrm{SaO}_{2}$} \\
\hline M & $98.1 \pm 0.3$ & $99.0 \pm 0.2$ & $98.8 \pm 0.2$ & $98.2 \pm 0.3$ & $97.8 \pm 0.3$ & $97.4 \pm 0.3$ & $96.2 \pm 0.4$ & $96.7 \pm 0.4$ \\
\hline$S$ & $98.5 \pm 0.3$ & $98.0 \pm 0.3$ & $98.8 \pm 0.3$ & $98.0 \pm 0.3$ & $97.3 \pm 0.6$ & $97.5 \pm 0.3$ & $97.2 \pm 0.2$ & $96.9=0.3$ \\
\hline
\end{tabular}

There were no significunt differences between groups. Epid = print to epidural lidncaine, Inc = skin incisinn, Del = dejivery; Min refers to number of minutes following administration of meperidine or saline. Data are only for patients receiving intravenous ueatment for shivering ( $n=20$ in each group). 
venous oxygen saturation, and increase demand on ventilation such that hypoxaemia and acidosis develop. .5.15-17 $^{\text {. }}$ Thus, muscle activity involved in shivering may be both distressing and potentially hazardous to the parturient.

The incidence of shivering in the present study was very high, even before epidural andesthesia was established ( 43 per cent in the meperidine group and 65 per cent in the saline group). By delivery, the majority of patients (87 per cent) were shivering, many ( 57 per cent), severely so. Various mechanisms have been invoked to explain the shivering observed during epidural anaesthesia including decreases in core temperature and misinformation from receptors. Decreases in core temperalure may be due to sympathetic blockade which results in peripheral vasodilatation, increased cutaneous blood flow, and subsequent increased heat lost via skin. ${ }^{14,18} \mathrm{~A}$ fall in core temperature may also be due to a cold operating room, or the rapid infusion of crystalloid solutions at room temperature. .9-21 $^{19}$ Shivering with epidural anaesthesia may also result from the differential inhibition of afferent themoreceptors fibres within the spinal cord ${ }^{22}$ or direct effects of cold anaesthetic solutions upon thermosensitive structures within the spinal cord. ${ }^{23}$ As well, local anaesthetics introduced into the epidural space might act to modify environmental thermal cues, with resultant inappropriate thermal responses to false information. ${ }^{24}$

Based on these mechanisms, various authors have attempted to reduce the incidence of shivering in their patients. Successful treatment modalities for non-obstetric patients have included covering the patient with blankets and/or warming the operating room suite. ${ }^{14,19}$ Other modalities such as warming the local anaesthetic solu$\operatorname{tion}^{3,20}$ or warming the intravenous fluids ${ }^{21.25}$ have met with varying degrees of success. For example, Webb et $a l{ }^{3}$ were unable to show any difference in incidence of shivering between epidural bupivicaine $(0.25$ per cent, 10 ml) at 15,20 or $37^{\circ} \mathrm{C}$, despite similar levels of analgesia in 48 labouring patients. Similarly, McCaroll et al. ${ }^{25}$ were unable to document any benefit of administering warmed $\left(34^{\circ} \mathrm{C}\right.$ ) intravenous fluids ( 0.9 per cent saline, $2 \mathrm{~L})$ compared with fluids at room temperature in a randomized study of 40 patients undergoing elective Caesarean section with epidural lidocaine 2 per cent. In fact, the incidence of shivering was higher in patients receiving the warmed fluids ( 55 versus 35 per cent).

Meperidine has previously been shown to be effective in the non-obstetric treatment of postanaesthetic shivering following general anaesthesia with volatile or narcotic based techniques, ${ }^{26}$ after cardiopulmonary bypass, ${ }^{5}$ and during chemotherapy with amphotericin $B$ infusions. ${ }^{8}$ Burks et al ${ }^{8}$ observed that 25 to $60 \mathrm{mg}$ of meperidine administered over 20 minutes was highly effective in treating the shaking chills and fever in 19 patients receiving amphotericin chemotherapy. Pauca et at. ${ }^{\top}$ administered meperidine (pethidine) in $5 \mathrm{mg}$ increments to 27 patients shivering after general anesthesia. This was found to be effective only at the higher cumulative dose (>20 mg). In constrast, morphine and fentanyl were not effective in decreasing shivering. ${ }^{7}$ Similarly, Claybon and Hirsh ${ }^{27}$ found a dose-response relationship for meperidine. Postoperative shivering ceased in 68 per cent of cases with $12.5 \mathrm{mg}$, in 75 per cent of cases with $25 \mathrm{mg}$ and in 89 per cent of cases with $50 \mathrm{mg}$. Guffin et al. ${ }^{9}$ found that mepcridine 25 or $50 \mathrm{mg}$ was effective in reducing the incidence of shivering and improving mixed venous oxygen saturation following cardiopulmonary bypass in 11 of 20 patients, whereas morphine 5 or $10 \mathrm{mg}$ was ineffective. In contrast, Harris et al ${ }^{28}$ were unable to demonstrate any protective effects of 12.5 or $25 \mathrm{mg}$ of meperidine in preventing shivering during extracorporeal shock wave lithotripsy under lidocaine epidural anaesthesia. They were also unable to show any benefit from the administration of small doses of meperidine (6.25, 12.5 or $25 \mathrm{mg}$ ) in the treatment of subsequent shivering.

The present study documents that a single dose of 50 $\mathrm{mg}$ meperidine reduces both the incidence and severity of shivering during Caesarean section under epidural anaesthesia. The drug was given in a randomized, double-blind fashion, and was especially effective in eliminating the severe grade 3 shivering. The administration of meperidine appeared to be safe in our patients, although there was an initial period of drowsiness (two and five minutes post drug injection). However, the levels of consciousness were similar between groups within 15 minutes of drug administration. Respiratory rate and oxygen saturation were both maintained within normal limits, as were arterial pressure and heart rate. As well, the incidence of nausea and the requirements for anti-emetics and anxiolytics were similar between groups.

The mechanism of action of meperidine on reducing shivering is uncertain. It may include a central action, perhaps related to that of taurine. Taurine is a sulfur containing neurotransmitter which inhibits central heat production and conservation pathways. ${ }^{29.30}$ Murphy et al..$^{31}$ de monstrated that intracerebroventricular and irtravenous administration of this putative inhibitory neurotransmitter stopped the shivering in unoperated squirrel monkeys anaesthetised with halothane and nitrous oxide. Another possible mechanism of action of meperidine could be via modulation of nociceptive and temperature information in the brain, spinal cord or rexed laminae, mediated through one or more of the recognized subpopulations of opioid receptors. ${ }^{32}$ However, the failure of other opiates such as morphine or fentanyl in reducing the incidence of shivering following cardiopulmonary bypass or general anaesthesia ${ }^{5,7,27}$ makes this theory less likely. 
Recently, the application of radiant heat to the face and chest was shown to be highly effective in inhibiting postanaesthetic shivering in patients undergoing various surgical procedures (including elective Caesarean section) with spinal, epidural or general anaesthetic techniques ${ }^{33}$ This may be due to the activation of "warmth receptors" that are densely distributed in the blush region, which may alter the thermal signals reaching the nervous system and thus inhibit postanaesthetic shivering despite low core temperature. ${ }^{33}$ One can therefore speculate that meperidine may exert some effect on these "wamth receptors."

In summary, shivering during epidural anaesthesia was a common complication in patients undergoing emergency Caesarean section. The high incidence of shivering may be due to decreases in core temperature secondary to peripheral vasodilation from sympathetic blockade and/or cold intravenous fluids. As well, effects of cold epidural solutions on thermoregulating structures and/or other mechanisms may also play a role. Shivering in these patients may be successfully and safely treated with intravenous meperidine after delivery of the infant. The mechanism of action of meperidine on shivering remains to be answered.

\section{References}

1 Ostheimer $G W$, Datta $S$. Observations in the postpartum rccovery room after various local anaesthetic techniques. Regional Anesthesia 1981; 6: 13-7.

2 Jaomeri KEU, Jahkola A, Perttu J. On shivering in association with normal delivery. Acta Obster Gynecol Scand 1966; 45: 383-8.

3 Webb PJ, James FM, Wheeler AS. Shivering during epidural analgesia in women in tabor. Anesthesiology 1981; 55: 706-7

4 Bay $J, N u n n J F$, Prys Roberts $C$. Factors influencing arterial $\mathrm{PO}_{2}$ during recovery from anaesthesia. $\mathrm{Br} \mathrm{J}$ Anaesth 1968; 40: 398-407.

5 Prys Roberts $C$. Post-anesthesia shivering. In: Artusio JF, ed. Clinical ancsthesia. Philadelphia: FA Davis, 1968: 358.

6 Holdcroft $A$, Hail GM. Heat loss during anaesthesia. Br J Anaesth 1978; 50: 157-64

7 Pauca AL, Sauage RT, Simpson S, Ray RC. Effect of pethidine, fentany? and morphine on post-operative shivering in man. Acta Anacsthesiol Scand 1984, 28: 138-43.

8 Burks C, Aisner J, Foster CL et al. Meperidine for the treatment of shaking chills and fever. Arch Intern Med $1980 ; 140: 483-4$.

9 Guffin A, Girard D, Kaplan JA. Shivering following cardiac surgery: haemodynamic changes and reversal. $J$ Cardiother Anesth 1987; 1: 24-8.
10 Dixon WJ, Massey FJ. Introduction to Statistical Analysis. 3rd cdition, McGraw Hill Book Co., New York 1969.

11 Swinsiow TDV. Statistics at Square One. British Medical Association, London 1977

12 Siegel S. Nonparametric Statistics for the Behavioural Sciences. McGraw Hill Book Co., New York 1956.

13 Downing JW. Bupivacaine: a clinical assessment in lumbar extradural block. Br J Anacsth 1969; 41: 427-32.

14 Waters $H R$, Rosen $N$, Perkins $D H$. Extradural blockade with bupivacaine. Anaesthesia 1970; 25; 184-90.

15 Roe CF, Goldberg $M J$, Blair CS, Kinney $J M$. The influence of body temperature on carly postoperative oxygen consumption. Surgery 1966;60: 85-92.

16 Jones HD, McLaren CAB. Postoperative shivering and hypoxaemia after halothane, nitrous oxide and oxygen anaesthesia. Br J Anaesth 1965; 37: 35-41.

17 Horvarh SM, Spurr $C B$, Hur BK, Hamilton LH. The metabolic cost of shivering. J Appl Physiol 1956; 8: 595-602.

18 Chamberiain DP, Chamberlain DDL. Changes in the skin temperature of the trunk and their relationship to sympathetic blockade during spinal anesthesia. Anesthesiology 1986; 65: 139-43.

19 Pflug AE, Aasheim GM, Foster C, Martin RW. Prevention of postanaesthesia shivering. Can Anaesth Soc J 1978; 25: 43-9.

20 Walmsley AJ, Giesecke AH, Lipton JM. Epidural temperature: a cause of shivering during epidural anesthesia. Anesth Analg 1986; 65: S164.

21 Workhoven NM. Intravenous fluid temperature, shivering and the parturient. Anesth Analg 1986; 65; 496-8.

22 Fruhsiorfer $H$, Zenz $M$, Nolte $H$ et al. Dissociated loss of cold and warm sensibility during regional anaesthesia. Pfluegers Arch 1974; 349: 73-82.

23 Thater $R$, Simon $E$. Spinal cord and temperature regulation. Advances in Climatic Physiology. Ito $\mathbf{S}$, Ogata $\mathbf{K}$, Yoshimura H (Eds). Tokyo, Izaku Shoin Ltd., 1972; pp. 22-49.

24 Bromage $P R$. Epidural Analgesia. Philadelphia: WB Saunders Co., 1978; pp. 394-6.

25 McCarroll SM, Carnwright P, Weeks SK, Donati F. Warming intravenaus fluids and the incidence of shivcring during Caesarean section under epidural anaesthesia. Can J Anaesth 1986; 33: S72-\$73.

26 Holdcroft A, Hall GM, Cooper GM. Redistribution of body heat during anaesthesia. Anaesthesia 1979; 34: 758-64.

27 Claybon LE, Hirsh RA. Meperidine arrests post-anesthesia shivering. Anesthesiology 1980; 53: $\$ 180$.

28 Harris MM, Arnold WP, Lawson D, Ellis JE. Meperidine does not prevent shivering following epidural lidocaine. Regional Anesthcsia 1987; 12: 57-8.

29 Harris WS, Lipion JM. Intracenebroventricular taurine 
in rabbits: effects on normal body temperature, endotoxin fever and hyperthermia produced by $P G E_{1}$ and amphetamine. J Physiol (Lond) 1977; 266: 397-410.

30 Clark SM, Lipton $J M$. Hypothermia produced in aged squirrel monkeys by central administration of teurine. Exp Aging Res 1981; 7: 17-24.

31 MurphyMT, LiptonJM, Louglran P, Giesecke JrAH. Postanesthetic shivering in primates: inhibition by peripheral heating and by taurine. Anesthesiology 1985; 63: 161-5.

32 Yaksh TL. Multiple opioid receptor systems in brain and spinal cord. Par I. Eur J Anaesthesiol 1984; 1: 171-99.

33 Sharkey A, Lipron IM, Murphy MT. Gicsecke AH. Inhibition of postanesthetic shivering with radiant heat. Anesthesiology 1987; 66: 249-52.

\section{Résumé}

Afin de déterminer l' efficacité de la mépéridine dans le contrôle des frissons lors d" une anesthésie épidurale pour césartentne, 46 parrurientes ont été étudiées. Après l' accouchement de l' enfant, les patientes avant frissonné ont reçu à double insu soit une dose unique intraveineuse de mépéridine $50 \mathrm{mg}$ ou du salin après randomisation. Les frissons ont été classiffiés selon une échelle de 0 à 3 (grade $0=$ aucun, grade $3=$ frisson sévère qui était inconforsable pour la patiente et interférant avec la surveillance). Les frissons ainsi que d"autres variables ont été enregistrés lors de la me en place de l'épidurale, Iincision. laccouchement, et d 2,5,15,30 et 60 minutes après l"injection. L'administration de mépéridine provoqua une diminution significative de l'incidence toale des frissons (87 a 35 puur cent, $p<0.01$ ) ainsi que de la sévérité des frissons (grade 3:57 à Opour cent, $p<0.01$ ), compararivement au salin (incidence: 87 à 83 pour cent, grade $3: 57$ pour cent, aucun changement). Cet effet était apparent en dedans de deux minutes après l'injection du médicament et persisia tout le long de l'étude. Il n'y avait aucune différence dans les signes vitaux, la saturation d'oxygène ou la température entre les groupes. L'incidence des nausés était identique même si les patientes avant reçu la mépéridine éraient plus somnolentes à 2 et 5 minutes après l'injection $(p<0.01)$ comparativement au groupe salin. Il n'y avait aucune différence dans le riveau de conscience aux autres phases de l'étude. Le mécanisme d'action de la mépéridine sur les frissons demeure à être élucidé. 